\title{
The Correlation Between Working Load and Pressure in the Practical Units for the Students of Family Welfare Education Department, Faculty of Engineering, UNNES
}

\author{
Saptarianna ${ }^{1}$ \\ ${ }^{1}$ Home Economic, Semarang State University, Engineering Faculty, Sekaran Gunungpati, Semarang, Indonesia \\ saptariana@mail.unnes.ac.id
}

Keywords: Students of the family welfare department, practical units' working loads, practical units' working pressure

Abstract: $\quad$ According to President Regulation Number 8 the Year 2012 regarding the Framework of Indonesian National Qualification, the Educational Institution should cater to the needs of Vocational Education and Working Fields. Concerning the issue, the institution should conduct practical units to match students' skills with the working industries. From the initial analysis, the practical units in the Family Welfare Education Department of Faculty of Engineering, Universitas Negeri Semarang should review the students' maximum working load. Thereby, it also strengthens students' working competence. The high intensity of studying load will make the students challenging to focus and unable to master the lecturing materials deeply. Moreover, the number of units to take in Indonesian education is too much for undergraduate students. This research is descriptive research which objects the curriculum and the students of the Family Welfare Education Department in UNNES. The researchers gathered the data from questionnaires with focuses on the students' working loads and pressures. Then, the researchers analyzed the data with a description of statistics. As a conclusion, there are two points in this research: 1). The working loads for students in Culinary, Fashion, Beauty, and Family Welfare Education programs are in a moderate category; and 2) the working pressure for the students in the programs above are in a low category.

\section{INTRODUCTION}

According to President Regulation Number 8 the Year 2012 regarding the Framework of Indonesian National Qualification, the Educational Institution should cater to the needs of Vocational Education and Working Fields. Concerning the issue, the institution should conduct practical units to match students' skills with the working industries. The education system should implement a technologicalbased curriculum to adapt to the dynamics of technological development in the moving industries The idea is suitable for Vocational teachers who will teach in Vocational School.

From the initial analysis, the practical units in the Family Welfare Education Department of Faculty of Engineering, Universitas Negeri Semarang should review the students' maximum working load. Thereby, it also strengthens students' working competence. About the significance of higher education, students who achieved lower Grade Point Average say that "in reality, we need the practical understanding more than the theories. We can adapt our theoretical understanding of the actual working fields". Meanwhile, the high achievers say that "practical understanding is useless without any theoretical grounds". The contradiction raised a question on which part is essential for students, theoretical understanding or practical implementation?

The high intensity of studying load will make the students challenging to focus and unable to master the lecturing materials deeply. Moreover, Doni Koesoema, an education observer, argues that the number of units to take in Indonesian education is too much for undergraduate students (kompasiana.com). In a week, students will be challenging to master too many materials. He adds that there should be an evaluation of the units for undergraduates so that students will not learn something beyond their capacity. Doni compares the studying loads in Indonesia to a foreign university. In his words, international universities emphasize on quality understanding and in-depth analysis. $\mathrm{He}$ 
brings the example of American Higher Education, where students only need to take fewer units to pass a semester. However, the units require the students to collaborate with their lecturers to build a supportive learning environment. In that setting, a group has four hours lecturing session with assignments and personal exploration. Hence, the outcome of the system is better than the Indonesian one, since students have individual responsibility which urges themselves to deepen their understanding.

From the background, the researchers propose a study related to the ideal condition for students in Indonesia to study and have a practical unit. This research fonmons on tho numinisulum of nmontinol wnito in the Family Welfare Education Department in UNNES. Despite the long period of analysis, the study has the goal of becoming scientific guidance to bring the department into better systemic condition.

This research has three questions to answer:

1. How is the management of practical units in the Family Welfare Education Department?

2. How is the students' achievement after taking the practical units?

3. How is the working loads and pressure in the units?

This research is following the Strategic Plan of UNNES as follows.

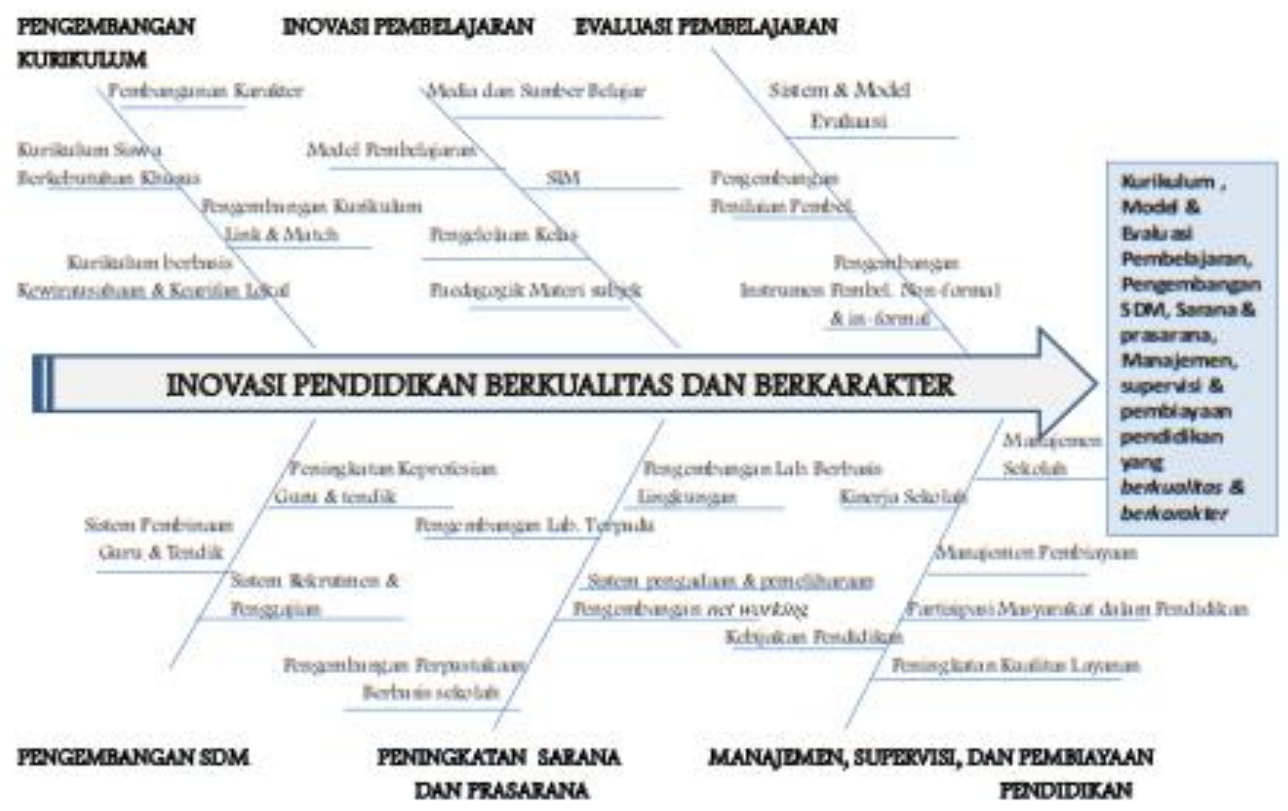

Figure 1. Strategic Plan of UNNES

From the Strategic Plan of UNNES, this research is a research of educational policy. The outcome of this research aims to strengthen the practical units in the Family Welfare Department of UNNES.

\section{LITERATURE REVIEWS 2.1 Practical Learning}

Practical learning is a process to enhance students' skills by employing various methods and utilities. Also, learning is a process which functions to guide students systematically to acquire new skills. The practice is an effort for people to experience. From experience, people can reflect new abilities based on their experiences.

Direct experience is vital in the learning process. It is valid for an adult learner to make them active in classroom activities. Based on the theory of experimental learning, there are four modes of

learning: concrete experience, reflective observation, abstract conceptualization, and active experimentation. Besides, Wallace says that knowledge comes from a formal and informal acquisition. Informally, people can either receive or experience knowledge. Both sources are essential for students' professional development. Students bring their experiences in the classroom, which is useful to enhance their understanding based on the reflection process or the transfer of learning.

During practice, students are expected to observe, understand, compare, and solve problems. The objectives of practice are:

a. Reflecting students to real working industries, 
b. Extending students' information and training their mindset to explore an issue and analyze it comprehensively,

c. Widening students' general knowledge on future technological development in relevance to their working fields,

d. Providing proper solution during an internship.

\subsection{Equipment for Practice}

Readiness is critical to finish a job. Readiness is the prerequisite for people to interact with their way. It is an overall condition of a person to respond or answer questions in a problematic situation. Adaptation is essential when people react to something. The status for people's readiness cope with three aspects:

a. Physical, mental, and emotional condition.

b. Motives, goals, and requirement.

c. Skills and knowledge.

The practice is an activity for people to do something as in theory. To learn something, people need joyful and complete environment. They also need comprehensive and relevant facilities to optimize their achievement. The facility is something which eases people to do specific activities. The required actions are activities to achieve learning objectives. Learning facility can be a book, properties, media, practical tools, room, and other things to support the learning environment. Considering that facilities are essential, there should be proper planning for its procurement.

Organization and management of tools will support the learning process because facilities are the main elements of learning. Some things to consider for related to facilities are

a. Facilities should be available in the learning process,

b. Facilities can be modified,

c. Facilities are in line with the program.

The management of practical facilities is not the responsibility of the workshop manager, but also the responsibility of the students. The students are in charge of interacting and studying using useful types of equipment. The roles of the students in the management are:

a. The lending of the tools with the lending letter,

b. The maintenance of machine and tools by reporting to technicians,

c. The maintenance of the practical machine,

d. The storage of practice facilities based on their functions,

The description of the facilities is essential to support the learning environment. The completion and relevance of facilities will expectedly improve students' interest to do the practice.

\subsection{Working Loads and Pressure}

Stress is a physical response which is not specified according to the working loads. Stress comes if people have overloading tasks beyond their capacity (Selye, 1950 in Hidayat, 2011). Stress can happen if people do not finish their jobs.

The manifestation of stress is the character of the loads and the environmental aspects. Stress is related to the way people handle problems (Levin et al., 2004). Stress reaches its peak if people do not achieve better performance. If people have huge issues, their performance will decrease, since it disturbs their ability to handle tasks well and behave rationally. The worst-case might happen from stress is people become sick, feel worthless, and refuse to work (Munandar, 2008).

\section{RESEARCH METHODS}

This research is descriptive. The approach is a method which draws and interprets the object as it is. Descriptive research focuses on actual problems during investigation. Descriptive research requires people to describe actions and occurrences without giving special treatment to the case.

This research objects the curriculum of the Family Welfare Department and targets the students of the department. The department has several programs, including Culinary education, Fashion education, and Beauty education. The research employees proportional random sampling. The equivalent sample is a sampling method which focuses on a particular area. This research is based on the proportion of each research object. To gather the data in this research, the researchers assess the curriculum of the Family Welfare Department's programs. The researchers collect the data using questionnaires and observation sheets.

This research employs a descriptive statistical analysis. The researchers count the percentage of the students' working loads in number based on the units they have taken. The given units are based on the Decree of the Ministry of Education Number: 232/U/2000 regarding The Guidance of Curriculum in Higher Education and Students' Learning Outcome.

\section{FINDINGS AND DISCUSSION}

This research draws the problem of practical units in the Family Welfare Education Department based on the achievements and the execution of the units. 
From the first semester to the eighth, the most studying loads to take is 23 units with the lowest possible of 12 units. The students got practical units since the first semester. About the working loads and pressure, the following explanations provide information about students' responsibilities in each semester.

\subsection{Culinary Education}

Table 1. Practical Working Loads for Students of the Culinary Department

\begin{tabular}{|l|c|c|}
\hline Criteria & $\mathrm{n}$ & percentage \\
\hline Very Overwhelming & 0 & 0 \\
\hline Overwhelming & 0 & 0 \\
\hline Moderate & 7 & $12 \%$ \\
\hline Less Burdening & 50 & $83 \%$ \\
\hline Fine & 3 & $5 \%$ \\
\hline
\end{tabular}

Based on Table 1, Culinary students' perception of the practical units is $0 \%$ to very overwhelming

Table 3 and overwhelming, $12 \%$ to moderate, $83 \%$ to less burdening, and $5 \%$ to fine.

Table 2 provides the data of students' working pressure.

Table 2.

Culinary Education Students' Working Pressure Level in Practical Units

\begin{tabular}{|l|l|l|}
\hline Criteria & $\mathrm{n}$ & Percentage \\
\hline Oftenly Stressful in Practice & 0 & $0 \%$ \\
\hline $\begin{array}{l}\text { Moderately Stressful in } \\
\text { Practice }\end{array}$ & 30 & $50 \%$ \\
\hline Less Stressful in Practice & 30 & $50 \%$ \\
\hline
\end{tabular}

Based on the data above, the students' pressure feelings on their practical units are explained as $0 \%$ in often stressful, $50 \%$ in moderately stressful, $50 \%$ in less stressful in practice.

From both data, Table 3 provides the descriptive statistics analysis as follows.

Descriptive Statistics to the Data from Culinary Education Students

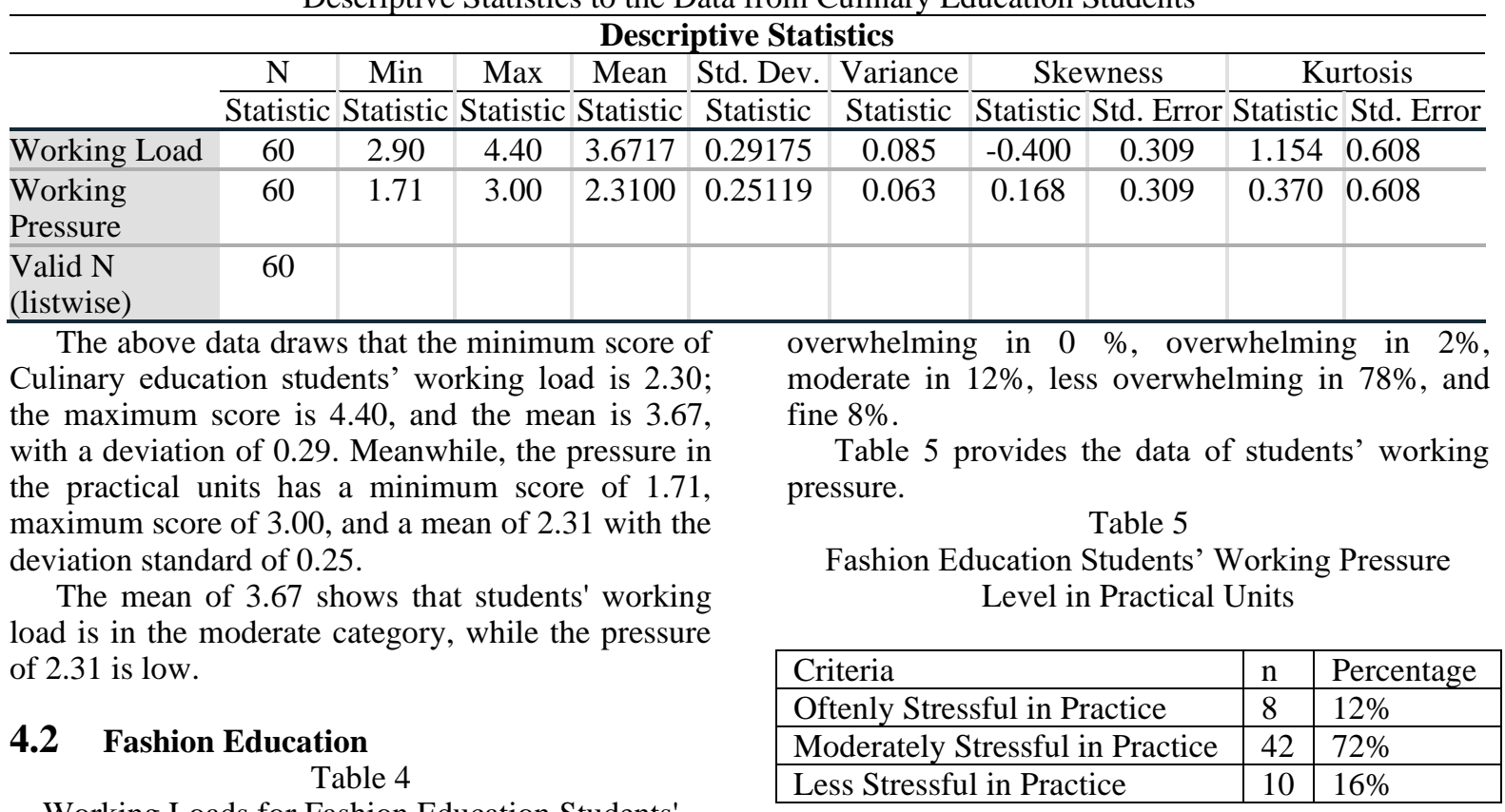

Working Loads for Fashion Education Students' Working Load

\begin{tabular}{|l|l|l|}
\hline Criteria & $\mathrm{N}$ & Percentage \\
\hline Very Overwhelming & 0 & 0 \\
\hline Overwhelming & 1 & $2 \%$ \\
\hline Moderate & 7 & $12 \%$ \\
\hline Less Burdening & 47 & $78 \%$ \\
\hline Fine & 5 & $8 \%$ \\
\hline
\end{tabular}

Based on the data above, the students' pressure feelings on their practical units are explained as $12 \%$ often stressful, $72 \%$ moderate, and $16 \%$ less stressful.

From both data, Table 6 provides the descriptive statistics analysis as follows.

Based on the above data, Fashion education students' perception to the practical units are very 
Table 6

Descriptive Statistics to the Data from Fashion Education Students

\begin{tabular}{|c|c|c|c|c|c|c|c|c|c|c|}
\hline \multicolumn{11}{|c|}{ Descriptive Statistics } \\
\hline & $\mathrm{N}$ & Min & Max & Mean & Std. Dev. & Variance & Skewne & & Kurtosi & \\
\hline & Statistic & Statistic & Statistic & Statistic & Statistic & Statistic & Statistic & Std. Error & Statistic & Std. Error \\
\hline Working Load & 60 & 2.40 & 4.50 & 3.7400 & 0.36509 & 0.133 & -1.033 & 0.309 & 2.384 & 0.608 \\
\hline $\begin{array}{l}\text { Working } \\
\text { Pressure }\end{array}$ & 60 & 1.11 & 2.54 & 2.0265 & 0.30313 & 0.092 & -0.785 & 0.309 & 0.440 & 0.608 \\
\hline $\begin{array}{l}\text { Valid } \\
\text { (listwise) }\end{array}$ & N60 & & & & & & & & & \\
\hline & & & & & Fin & & & 5 & & $8 \%$ \\
\hline
\end{tabular}

The above data draws that the minimum score of Fashion education students' working load is 2.40 ; the maximum score is 4.50 , and the mean is 3.74 , with a deviation of 0.38 . Meanwhile, the pressure in the practical units has a minimum score of 1.11 , maximum score of 2.54, and mean of 2.02 with the deviation standard of 0.30 .

The mean of 3.74 shows that students' working load is in the moderate category, while the pressure of 2.02 is low.

\subsection{Beauty Education}

Table 7

Working Loads for Beauty Education Students' Working Load

\begin{tabular}{|l|l|l|}
\hline Criteria & $\mathrm{n}$ & Percentage \\
\hline Very Overwhelming & 0 & 0 \\
\hline Overwhelming & 0 & $0 \%$ \\
\hline Moderate & 2 & $3 \%$ \\
\hline Less Burdening & 53 & $89 \%$ \\
\hline
\end{tabular}

Based on Table 1, Culinary students' perception of the practical units is $0 \%$ to very overwhelming and overwhelming, $3 \%$ to moderate, $89 \%$ to less burdening, and $8 \%$ to fine.

Table 8 provides the data of students' working pressure.

Table 8

Culinary Education Students’ Working Pressure Level in Practical Units

\begin{tabular}{|l|l|l|}
\hline Criteria & $\mathrm{n}$ & Percentage \\
\hline Oftenly Stressful in Practice & 1 & $2 \%$ \\
\hline Moderately Stressful in Practice & 44 & $73 \%$ \\
\hline Less Stressful in Practice & 15 & $25 \%$ \\
\hline
\end{tabular}

Based on the data above, the students' pressure feelings on their practical units are explained as $2 \%$ in often stressful, $73 \%$ in moderately stressful, $25 \%$ in less stressful in practice.

From both data, Table 9 provides the descriptive statistics analysis as follows.

Table 9

Descriptive Statistics to the Data from Fashion Education Students

\begin{tabular}{|c|c|c|c|c|c|c|c|c|c|c|}
\hline & $\mathrm{N}$ & Min & Max & Mean & Std. Dev. & Variance & Skewnes & & Kurtosi & \\
\hline & $\overline{\text { Statistic }}$ & Statistic & Statistic & Statistic & Statistic & Statistic & Statistic & Std. Error & Statistic & Std. Error \\
\hline Working Load & 60 & 3.20 & 4.30 & 3.8533 & 0.23395 & 0.055 & -0.298 & 0.309 & 0.439 & 0.608 \\
\hline $\begin{array}{l}\text { Working } \\
\text { Pressure }\end{array}$ & 60 & 1.46 & 2.60 & 2.1535 & 0.24784 & 0.061 & -0.462 & 0.309 & 0.097 & 0.608 \\
\hline $\begin{array}{l}\text { Valid } \\
\text { (listwise) }\end{array}$ & N60 & & & & & & & & & \\
\hline
\end{tabular}

The above data draws that the minimum score of Beauty education students' working load is 3.20 ; the maximum score is 4.30 , and the mean is 3.85 , with a deviation of 0.23 . Meanwhile, the pressure in the practical units has a minimum score of 1.46, a maximum score of 2.60 , and mean of 2.15 with the deviation standard of 0.25 .

The mean of 3.85 shows that students' working load is in the moderate category, while the pressure of 2.15 is low.

\subsection{Family Welfare Education Program}

Table 10. The Working Loads for Family Welfare Education Students' Working Load

\begin{tabular}{|l|l|l|}
\hline Criteria & $\mathrm{n}$ & Percentage \\
\hline Very Overwhelming & 0 & 0 \\
\hline Overwhelming & 0 & $0 \%$ \\
\hline Moderate & 1 & $2 \%$ \\
\hline Less Burdening & 41 & $93 \%$ \\
\hline Fine & 2 & $5 \%$ \\
\hline
\end{tabular}


Based on the above data, Fashion education students' perception to the practical units is very overwhelming and overwhelming in $0 \%$, moderate in $2 \%$, less overwhelming in $93 \%$ and fine in $5 \%$.

Table 11 provides the data of students' working pressure.

Table 11. Family Welfare Education Students' Working Pressure Level in Practical Units

\begin{tabular}{|l|l|l|}
\hline Criteria & $\mathrm{n}$ & Percentage \\
\hline Oftenly Stressful in Practice & 1 & $2 \%$ \\
\hline Moderately Stressful in Practice & 28 & $64 \%$ \\
\hline Less Stressful in Practice & 15 & $34 \%$ \\
\hline
\end{tabular}

Based on the data above, the students' pressure feelings on their practical units are explained as $2 \%$ in often stressful, $64 \%$ in moderately stressful, $34 \%$ in less stressful in practice.
From both data, the following table provides the descriptive statistics analysis as follows in Table 12. The data draws that the minimum score of Beauty education students' working load is 3.30 ; the maximum score is 4.30 , and the mean is 3.87 , with a deviation of 0.21 . Meanwhile, the pressure in the practical units has a minimum score of 1.60 , a maximum score of 3.00 , and a mean of 2.25 with the deviation standard of 0.30 . The mean of 3.87 shows that students' working load is in the moderate category, while the pressure of 2.25 is low.

Table 12. Descriptive Statistics to the Data from Family Welfare Education Program's Students

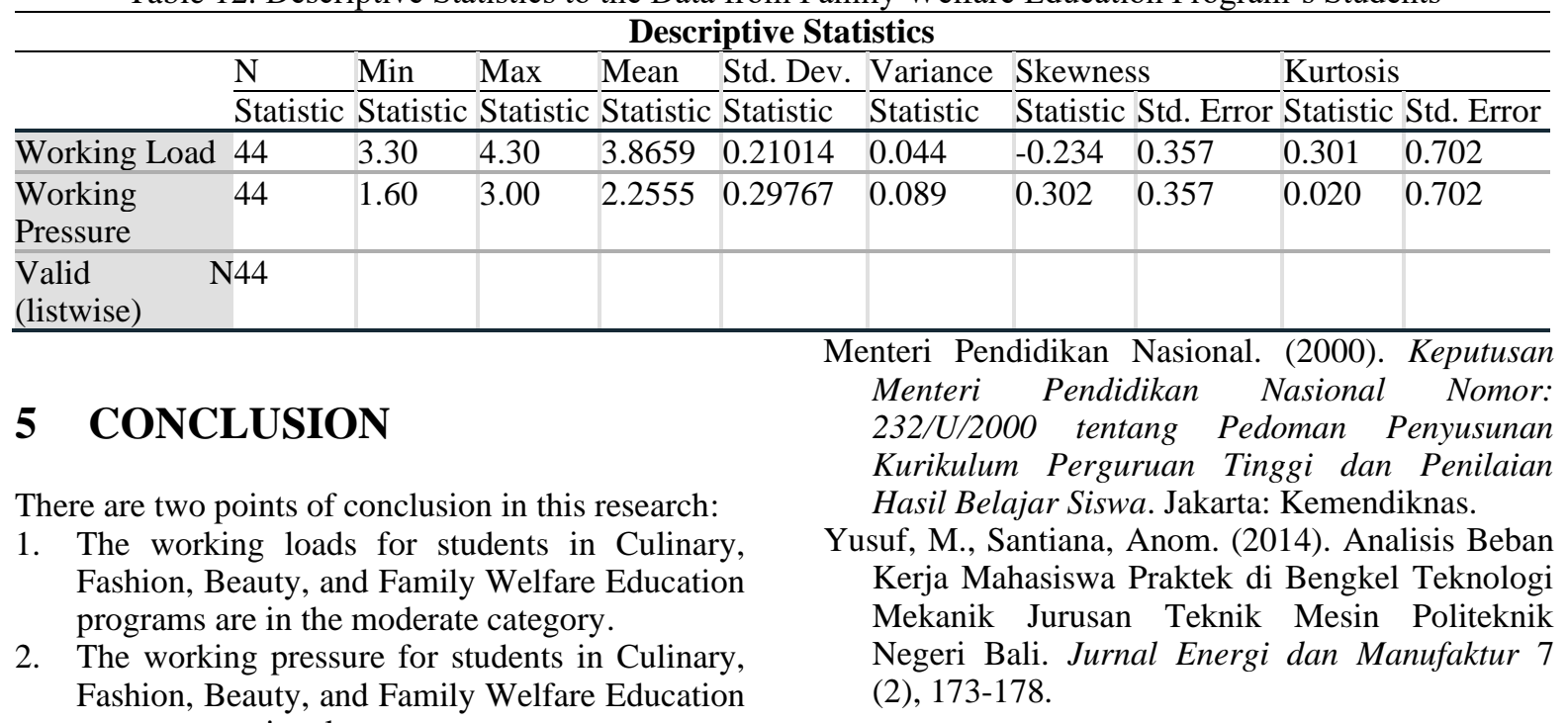

\section{REFERENCES}

Jurusan Teknologi Jasa dan Produksi. (2010). Silabus. Semarang: FT UNNES.

Hidayat, A .A. A. (2011). Pengantar Konsep Dasar Keperawatan. Jakarta: Salemba Medika.

Levin, S. (2004). Tracking Workload in the Emergency Department. The Journal of Human Factors and Ergonomics Society, 48 (3), 526539.

Munandar, A. S. (2001). Psikologi industri dan organisasi, edisi 1. Jakarta: UI Press.
Menteri Pendidikan Nasional. (2000). Keputusan 232/U/2000 tentang Pedoman Penyusunan Kurikulum Perguruan Tinggi dan Penilaian Hasil Belajar Siswa. Jakarta: Kemendiknas. Kerja Mahasiswa Praktek di Bengkel Teknologi Mekanik Jurusan Teknik Mesin Politeknik (2), 173-178 